\title{
Genomic Analyses Lead to Novel Secondary Metabolites
}

\section{Part $3^{\dagger}$ ECO-0501, a Novel Antibacterial of a New Class}

\author{
Arjun H. Banskota, James B. McAlpine, Dan Sørensen, Ashraf Ibrahim, Mustapha Aouidate, \\ Mahmood Piraee, Anne-Marie Alarco, Chris M. Farnet, Emmanuel Zazopoulos
}

Dedicated to the memory of Professor Kenneth Rinehart

Received: June 1, 2006 / Accepted: September 8, 2006

(C) Japan Antibiotics Research Association

\begin{abstract}
Genomic analyses of Amycolatopsis orientalis ATCC 43491 strain, deposited as a vancomycin producer, revealed the presence of genetic loci for the production of at least 10 secondary metabolites other than vancomycin. One of these gene clusters, which contained a type I polyketide synthase, was predicted to direct the synthesis of novel class of compound, a glycosidic polyketide ECO0501 (1). Screening of culture extracts for a compound with the predicted physicochemical properties of the product from this locus, led to the isolation of the 13-Oglucuronide of 13-hydroxy-2,12,14,16,22-pentamethyl-28( $N$-methyl-guanidino)-octacosa-2,4,6,8,10,14,20,24octaenoic acid (2-hydroxy-5-oxo-cyclopent-1-enyl)-amide (ECO-0501, 1). The structure, confirmed by spectral analyses including MS, and 1D and 2D NMR experiments, were in accord with that predicted by genomic analyses. ECO-0501 possessed strong antibacterial activity against a series of Gram-positive pathogens including several strains of methicillin-resistant Staphylococcus aureus (MRSA) and vancomycin-resistant Enterococci (VRE). ECO-0501 was chemically modified by esterification $(\mathbf{1 a} \sim \mathbf{1 c}), \mathrm{N}$ acetylation (1d) and hydrogenation (1e) in order to explore structure activity relationships (SAR).
\end{abstract}

Keywords Amycolatopsis orientalis, ECO-0501, antibacterial, PKS I

\section{Introduction}

Drug-resistant bacterial infections are a growing health concern. Resistance has been developed to every major class of antibiotics on the market, and an increasing number of pathogenic bacteria are becoming resistant to multiple classes of antibiotics, thereby limiting treatment options. Hence, there is a renewed urgency for the discovery of new classes of antibiotics for the treatment of drug resistant bacterial infections. To accelerate the discovery of such potential antibacterial candidates from natural resources a new, fast and efficient technology is needed. The genomics of secondary metabolite biosynthesis recently evolved to the point where analysis of the genome of an organism can define its biosynthetic capabilities for secondary metabolites. A genome scanning technique that has been developed in our laboratories, and used with our DECIPHER $^{\circledR}$ technology to analyze the genomes of actinomycetes for their secondary metabolite biosynthetic genes, greatly reduces the amount of sequencing required to define this capability $[1,2]$. This approach not only ascertains the potential of a producing organism, but it provides a handle to detect, isolate and structurally define a specific metabolite. We have demonstrated this approach in the isolation and structural determination of an antifungal

\footnotetext{
${ }^{\dagger}$ References 3 and 4 are considered as Parts 1 and 2, respectively, of this series.
}

J. B. McAlpine (Corresponding author), A. H. Banskota, D. Sørensen, A. Ibrahim, M. Aouidate, M. Piraee, A.-M. Alarco, C. M. Farnet, E. Zazopoulos: Ecopia BioSciences Inc., 7290 Frederick-Banting, Montréal, Québec, H4S 2A1, Canada, E-mail: mcalpine@ecopiabio.com 
agent, ECO-02301 from Streptomyces aizunensis [3] and three 5-alkenyl-3,3(2H)-furanones from two different Streptomyces species [4].

In this article, we are describing the use of the genome scanning technique $[5,6]$ to identify and isolate a novel class of antibacterial (ECO-0501) from the Amycolatopsis orientalis ATCC 43491 strain, which was deposited as a vancomycin producer. ECO-0501 possessed strong antibacterial activity against several, broadly resistant, Gram-positive pathogens.

\section{Results and Discussion}

A. orientalis ATCC 43491 was obtained from the American Type Culture Collection where it has been deposited as a vancomycin producer. Genomic analysis of this organism identified at least 10 gene clusters responsible for the biosynthesis of secondary metabolites other than vancomycin. Here we chose one of these to express and characterize the product; viz. a locus dominated by a type I polyketide synthase.

This locus spans approximately 100,000 base pairs of DNA and comprises 27 open reading frames (ORFs). The type I PKS system was predicted to generate a long polyketide backbone containing a polyene chromophore. More than $10 \mathrm{~kb}$ was analyzed on each side of the locus and these regions were deemed to contain primary genes or genes unrelated to the biosynthesis of secondary metabolites. The PKS system is composed of ORFs 18 to 23 in the locus, and comprises a total of 12 modules. The order, relative position and orientation of the ORFs representing the proteins of the PKS portion of the biosynthetic locus are illustrated schematically in Fig. 1. Immediately preceding the first module is an acyl carrier protein (ACP) domain, which specifies the loading unit. Each of the 12 modules contains $\beta$-ketoacyl protein synthase (KS), acyltransferase (AT) and acyl carrier protein (ACP) domains with various combinations with ketoreductase (KR), dehydratase (DH) and enoylreductase (ER) domains. The thioesterase (TE) domain present in ORF 23/module12 indicates that this module is the ultimate

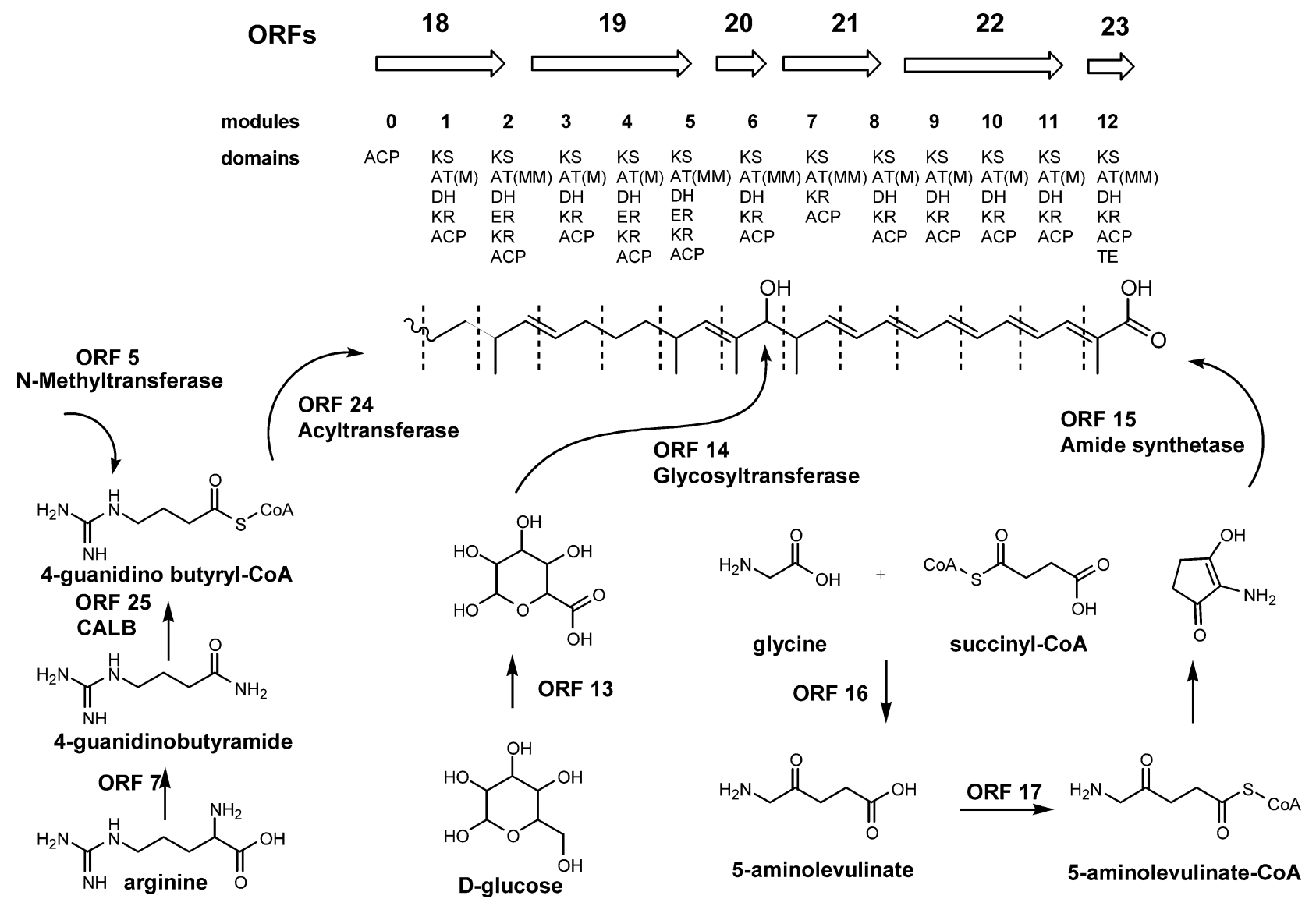

Fig. 1 PKS portion and some ancillary genes of the biosynthetic locus for ECO-0501 (1) in Amycolatopsis orientalis ATTC 43491. 


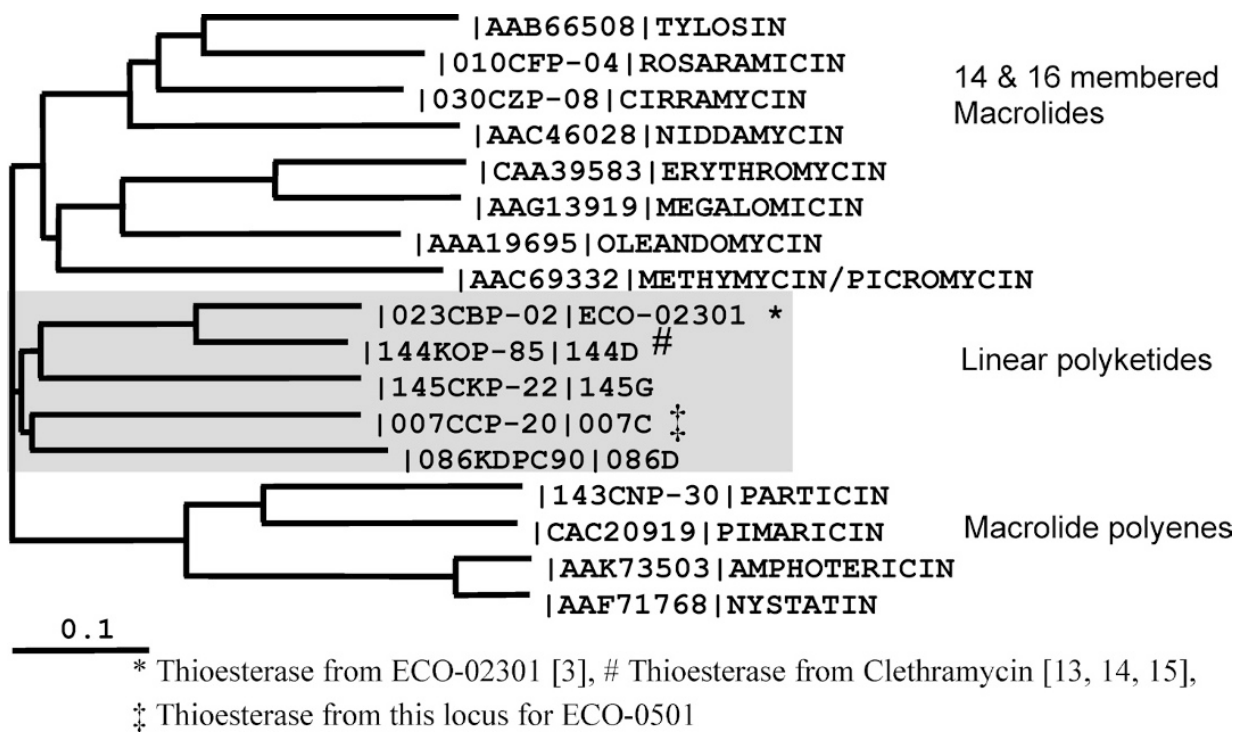

Fig. 2 Phylogenetic relationships between selected PKS I thioesterases from the DECIPHER ${ }^{\circledR}$ database.

one in the biosynthesis of the polyketide chain and phylogenetic analysis of the TE predicted a linear polyketide product (Fig. 2). Three ORFs $(7,25,24)$ in the cluster provided genes coding for enzymes with the capacity to convert arginine into 4-guanidinobutyryl-CoA and to load the activated 4-guanidinobutyryl group onto the loading ACP domain for the first PKS module, thus defining the likely starter unit for the polyketide. Two ORFs (16 and 17) provided the proteins for the synthesis of 5-aminolevulinate and its conversion through a coenzyme A ester to aminohydroxycyclopentenone, which is condensed onto the carboxy terminus of the polyketide chain by the enzyme encoded by ORF 15 . This pathway is supported by the fact that our previous antifungal agent ECO-02301 had a similar gene cluster, and the aminohydroxycyclopentenone moiety, found in the asukamycins, was reported formed via intramolecular cyclization of 5-aminolevulinate [7].

The sugar oxidoreductase encoded by ORF 13 oxidizes D-glucose to form D-glucuronic acid that is subsequently transferred onto a hydroxyl group of the polyketide chain through the action of the glycosyltransferase of ORF 14. As the polyketide chain had only one hydroxyl group, the position of glycosylation is unambiguous. Another gene in the cluster, (ORF 5) encoded an $N$-methyltransferase, which would transfer a methyl group from $S$-adenosylmethionine to the secondary nitrogen of the guanidine moiety. The full analysis of the gene cluster led to the prediction of a compound of a new structural class, a glycosidic polyketide containing a rare combination of guanidine, glucuronic acid and aminohydroxycyclopentenone groups (ECO-0501, 1).
To obtain expression of this gene cluster, $A$. orientalis ATCC 43491 was grown in shaken flasks in a dozen different fermentation media designed for the production of secondary metabolites. At harvest, an equal volume of $\mathrm{MeOH}$ was added to the broths, which were then vortexed and centrifuged. The supernatant liquid was then drawn off and concentrated to dryness. The resulting residue was re-suspended in $\mathrm{MeOH}$ and subjected to $\mathrm{HPLC} / \mathrm{MS} / \mathrm{UV}$ analyses. A number of these extracts contained a compound with UV absorption $\lambda_{\max }$ at $258 \mathrm{~nm}$ and a broad, poorly resolved, triple peak centered at $362 \mathrm{~nm}$, and MS peaks at $\mathrm{m} / \mathrm{z} 837.5$ (in positive mode) and 835.3 (in negative mode) corresponding to the properties predicted for the polyketide metabolite (ECO-0501, 1). Larger scale fermentations of A. orientalis ATCC 43491 were carried out in the most productive media for this metabolite and the target compound was then isolated by a series of fractionations followed by reversed phase HPLC, or by solid phase extraction (SPE) followed by reversed phase HPLC.

ECO-0501 (1) was isolated as a light yellow amorphous solid with molecular formula $\mathrm{C}_{46} \mathrm{H}_{68} \mathrm{~N}_{4} \mathrm{O}_{10}$ calculated from the MS data $\left[\mathrm{m} / \mathrm{z} 837.5(\mathrm{M}+\mathrm{H})^{+}\right.$and $\left.835.3(\mathrm{M}-\mathrm{H})^{-}\right]$. The ${ }^{1} \mathrm{H}$ NMR spectrum of $\mathbf{1}$ displayed fourteen olefinic protons together with five oxygenated methine protons, six methyl groups and nine methylene groups. In depth analyses of the gCOSY together with gHSQC spectra led to the definition of two large segments of the polyketide chain represented by bold line (Fig. 4) with a polyene chromophore. All the double bonds of the polyketide, including the two isolatedones as well as the ones in the polyene system, were considered to be trans-oriented based on the basis of the 
Table $1{ }^{1} \mathrm{H}$ and ${ }^{13} \mathrm{C}$ NMR data of compound 1

\begin{tabular}{|c|c|c|c|c|}
\hline No. & Group & ${ }^{1} \mathrm{H}$ & ${ }^{13} \mathrm{C}$ & $\operatorname{HMBC}\left({ }^{13} \mathrm{C}\right.$ to $\left.{ }^{1} \mathrm{H}\right)$ \\
\hline 1 & C & - & 170.1 & $7.09,2.06$ \\
\hline 2 & C & - & 138.8 & $7.09,6.38$ \\
\hline 3 & $\mathrm{CH}$ & 7.09 & 135.2 & 2.07 \\
\hline 4 & $\mathrm{CH}$ & 6.60 & 127.9 & \\
\hline 5 & $\mathrm{CH}$ & 6.38 & 132.5 & \\
\hline 6 & $\mathrm{CH}$ & 6.38 & 135.8 & \\
\hline 7 & $\mathrm{CH}$ & 6.56 & 127.9 & \\
\hline 8 & $\mathrm{CH}$ & 6.23 & 132.5 & \\
\hline 9 & $\mathrm{CH}$ & 6.23 & 131.3 & \\
\hline 10 & $\mathrm{CH}$ & 6.08 & 130.0 & \\
\hline 11 & $\mathrm{CH}$ & 5.51 & 137.9 & $3.58,1.21$ \\
\hline 12 & $\mathrm{CH}$ & 2.52 & 40.3 & $6.08,5.51,3.58,1.21$ \\
\hline 13 & $\mathrm{CH}$ & 3.58 & 93.8 & $5.51,5.03,4.20,2.52,1.60,1.21$ \\
\hline 14 & C & - & 134.3 & 1.61 \\
\hline 15 & $\mathrm{CH}$ & 5.03 & 136.4 & $3.58,1.61,0.92$ \\
\hline 16 & $\mathrm{CH}$ & 2.32 & 32.2 & $5.03,0.92$ \\
\hline 17 & $\mathrm{CH}_{2}$ & 1.13 & 37.4 & $1.87,0.92$ \\
\hline 18 & $\mathrm{CH}_{2}$ & 1.29 & 37.3 & 1.87 \\
\hline 19 & $\mathrm{CH}_{2}$ & 1.87 & 32.9 & $5.24,5.27$ \\
\hline 20 & $\mathrm{CH}$ & 5.24 & 135.9 & 1.87 \\
\hline 21 & $\mathrm{CH}$ & 5.27 & 129.3 & $1.87,0.96$ \\
\hline 22 & $\mathrm{CH}$ & 2.11 & 37.3 & $5.27,0.96$ \\
\hline 23 & $\mathrm{CH}_{2}$ & 1.97 & 40.6 & $5.42,0.96$ \\
\hline 24 & $\mathrm{CH}^{2}$ & 5.41 & 130.0 & $2.01,1.97$ \\
\hline 25 & $\mathrm{CH}$ & 5.41 & 130.0 & $2.01,1.97$ \\
\hline 26 & $\mathrm{CH}_{2}$ & 2.01 & 29.6 & $5.42,1.65$ \\
\hline 27 & $\mathrm{CH}_{2}$ & 1.64 & 27.2 & \\
\hline 28 & $\mathrm{CH}_{2}$ & 3.34 & 48.2 & $3.00,1.64$ \\
\hline 29 & $\mathrm{CH}_{3}$ & 2.06 & 12.4 & \\
\hline 30 & $\mathrm{CH}_{3}$ & 1.21 & 17.4 & $5.51,3.58$ \\
\hline 31 & $\mathrm{CH}_{3}$ & 1.60 & 11.4 & $5.03,3.58$ \\
\hline 32 & $\mathrm{CH}_{3}$ & 0.92 & 20.7 & 5.03 \\
\hline 33 & $\mathrm{CH}_{3}$ & 0.97 & 20.3 & 1.97 \\
\hline $1^{\prime}$ & $\mathrm{C}$ & - & 111.4 & 2.35 \\
\hline $2^{\prime}$ & C & - & 199.3 & 2.35 \\
\hline $3^{\prime}$ & $\mathrm{CH}_{2}$ & 2.35 & 31.0 & 2.35 \\
\hline $4^{\prime}$ & $\mathrm{CH}_{2}$ & 2.35 & 31.0 & 2.35 \\
\hline $5^{\prime}$ & $C^{2}$ & - & 199.3 & 2.35 \\
\hline $1^{\prime \prime}$ & $\mathrm{CH}$ & 4.20 & 102.9 & $3.59,3.27$ \\
\hline $2^{\prime \prime}$ & $\mathrm{CH}$ & 3.27 & 74.6 & 3.36 \\
\hline $3^{\prime \prime}$ & $\mathrm{CH}$ & 3.36 & 77.6 & $3.41,3.27$ \\
\hline $4^{\prime \prime}$ & $\mathrm{CH}$ & 3.41 & 72.9 & $3.40,3.36$ \\
\hline $5^{\prime \prime}$ & $\mathrm{CH}$ & 3.40 & 76.2 & 3.41 \\
\hline $6^{\prime \prime}$ & C & - & 176.1 & 3.41 \\
\hline $1^{\prime \prime \prime}$ & C & - & 157.7 & 3.00 \\
\hline $1^{\prime \prime \prime \prime}$ & $\mathrm{CH}_{3}$ & 3.00 & 35.8 & 3.30 \\
\hline
\end{tabular}


Table 2 The ${ }^{1} \mathrm{H}$ NMR data of $\mathbf{1 a} \sim \mathbf{1 e}$

\begin{tabular}{|c|c|c|c|c|c|c|}
\hline Position & Group & $1 a$ & $1 b$ & $1 c$ & $1 d$ & $1 \mathrm{e}$ \\
\hline 2 & $\mathrm{C} / \mathrm{CH}$ & - & - & - & - & 2.52 \\
\hline 3 & $\mathrm{CH} / \mathrm{CH}_{2}$ & 7.07 & 7.09 & 7.07 & 7.10 & * \\
\hline 4 & $\mathrm{CH} / \mathrm{CH}_{2}$ & 6.60 & 6.60 & 6.60 & 6.60 & * \\
\hline 5 & $\mathrm{CH} / \mathrm{CH}_{2}$ & 6.40 & 6.39 & 6.41 & 6.39 & * \\
\hline 6 & $\mathrm{CH} / \mathrm{CH}_{2}$ & 6.40 & 6.39 & 6.41 & 6.39 & * \\
\hline 7 & $\mathrm{CH} / \mathrm{CH}_{2}$ & 6.59 & 6.54 & 6.59 & 6.56 & * \\
\hline 8 & $\mathrm{CH} / \mathrm{CH}_{2}$ & 6.24 & 6.23 & 6.25 & 6.23 & * \\
\hline 9 & $\mathrm{CH} / \mathrm{CH}_{2}$ & 6.24 & 6.23 & 6.25 & 6.23 & * \\
\hline 10 & $\mathrm{CH} / \mathrm{CH}_{2}$ & 6.10 & 6.11 & 6.11 & 6.10 & * \\
\hline 11 & $\mathrm{CH} / \mathrm{CH}_{2}$ & 5.51 & 5.48 & 5.52 & 5.50 & * \\
\hline 12 & $\mathrm{CH}$ & 2.52 & 2.50 & 2.52 & 2.52 & 1.72 \\
\hline 13 & $\mathrm{CH}$ & 3.66 & 3.66 & 3.66 & 3.57 & 3.47 \\
\hline 15 & $\mathrm{CH}$ & 5.03 & 5.02 & 5.02 & 5.03 & 5.07 \\
\hline 16 & $\mathrm{CH}$ & 2.30 & 2.30 & 2.30 & 2.30 & 2.43 \\
\hline 17 & $\mathrm{CH}_{2}$ & 1.11 & 1.15 & 1.15 & 1.11 & * \\
\hline 18 & $\mathrm{CH}_{2}$ & 1.31 & 1.29 & 1.29 & 1.29 & * \\
\hline 19 & $\mathrm{CH}_{2}$ & 1.87 & 1.87 & 1.89 & 1.88 & * \\
\hline 20 & $\mathrm{CH} / \mathrm{CH}_{2}$ & 5.24 & 5.29 & 5.28 & 5.24 & * \\
\hline 21 & $\mathrm{CH} / \mathrm{CH}_{2}$ & 5.30 & 5.31 & 5.30 & 5.27 & * \\
\hline 22 & $\mathrm{CH}$ & 2.11 & 2.11 & 2.11 & 2.10 & 1.42 \\
\hline 23 & $\mathrm{CH}_{2}$ & 2.01 & 2.00 & 2.02 & 1.97 & * \\
\hline 24 & $\mathrm{CH} / \mathrm{CH}_{2}$ & 5.41 & 5.42 & 5.43 & 5.41 & $*$ \\
\hline 25 & $\mathrm{CH} / \mathrm{CH}_{2}$ & 5.41 & 5.42 & 5.43 & 5.41 & * \\
\hline 26 & $\mathrm{CH}_{2}$ & 2.03 & 2.02 & 2.01 & 2.01 & * \\
\hline 27 & $\mathrm{CH}_{2}$ & 1.66 & 1.64 & 1.67 & 1.65 & 1.65 \\
\hline 28 & $\mathrm{CH}_{2}$ & 3.34 & 3.35 & 3.35 & 3.34 & 3.35 \\
\hline 29 & $\mathrm{CH}_{3}$ & 2.04 & 2.07 & 2.04 & 2.06 & 1.18 \\
\hline 30 & $\mathrm{CH}_{3}$ & 1.19 & 1.20 & 1.19 & 1.21 & 1.08 \\
\hline 31 & $\mathrm{CH}_{3}$ & 1.60 & 1.52 & 1.52 & 1.57 & 1.62 \\
\hline 32 & $\mathrm{CH}_{3}$ & 0.91 & 0.89 & 0.89 & 0.91 & 0.97 \\
\hline 33 & $\mathrm{CH}_{3}$ & 0.95 & 0.95 & 0.95 & 0.95 & 0.89 \\
\hline 2'-OMe & $\mathrm{CH}_{3}$ & 4.06 & - & 4.07 & - & - \\
\hline $3^{\prime}$ & $\mathrm{CH}_{2}$ & 2.51 & 2.36 & 2.51 & 2.37 & 2.44 \\
\hline $4^{\prime}$ & $\mathrm{CH}_{2}$ & 2.84 & 2.36 & 2.84 & 2.37 & 2.44 \\
\hline $1^{\prime \prime}$ & $\mathrm{CH}$ & 4.21 & 4.26 & 4.26 & 4.24 & 4.22 \\
\hline $2^{\prime \prime}$ & $\mathrm{CH}$ & 3.28 & 3.26 & 3.26 & 3.31 & 3.28 \\
\hline $3^{\prime \prime}$ & $\mathrm{CH}$ & 3.37 & 3.29 & 3.30 & 3.37 & 3.36 \\
\hline $4^{\prime \prime}$ & $\mathrm{CH}$ & 3.41 & 3.51 & 3.51 & 3.53 & 3.40 \\
\hline $5^{\prime \prime}$ & $\mathrm{CH}$ & 3.40 & 3.54 & 3.56 & 3.54 & 3.45 \\
\hline 6"-OMe & $\mathrm{CH}_{3}$ & - & 3.73 & 3.73 & - & - \\
\hline $1^{\prime \prime \prime}-\mathrm{OAc}$ & $\mathrm{CH}_{3}$ & - & - & - & 2.06 & - \\
\hline $1^{\prime \prime \prime \prime}$ & $\mathrm{CH}_{3}$ & 3.02 & 2.98 & 3.01 & 3.00 & 3.04 \\
\hline
\end{tabular}

* The methylene signals were overlap at $\delta$ 1.40 1.20. 


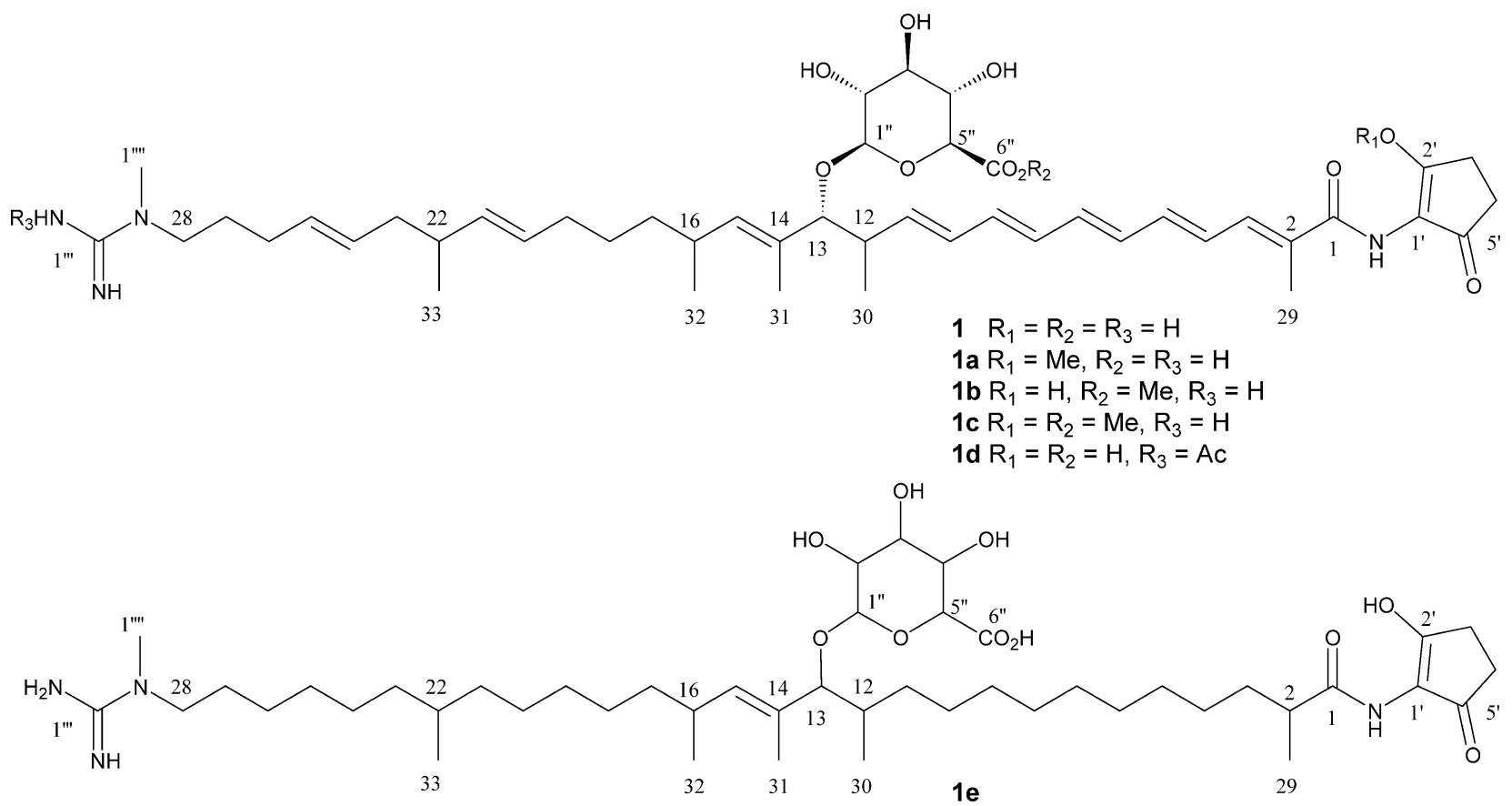

Fig. 3 The structures of ECO-0501 (1) and the derivatives 1a $\mathbf{1 e}$.

ketoreductases present in the polyketide synthase system. Indeed, analysis of the ketoreductases enables prediction of the stereoconfiguration of the alcohol (D or L) generated through their enzymatic activity. Subsequent action of the dehydratases will generate a trans- or cis-double bond upon dehydration of a D- or an L-alcohol respectively. All ketoreductases present in the ECO-0501 polyketide system were predicted to generate D-alcohols with the exception of the KR present in module 7, indicating that the only alcohol present in the molecule is in the L stereoconfiguration [8]. The stereochemistry of carbon 13 as shown in Fig. 3 is based only on the genomic data and that of the glucuronic acid moiety is based on carbon chemical shifts [9]. The stereochemistry of the double bonds was confirmed by the observed coupling constant values $(>14.5 \mathrm{~Hz})$. The longrange correlations observed between methyl groups at $\delta$ 1.60 and 1.21 to carbon at $\delta 93.8$ in the gHMBC spectrum together with the additional HMBC correlations of methyl protons at $\delta 1.60$ with carbons at $\delta 136.4$ and 134.3 suggested the two parts of polyketide chain constructed by COSY and HSQC spectral analyses were joined via a quaternary carbon at $\delta 134.4$ (C-14). Moreover, the HMBC correlations between methyl group at $\delta 2.00$ and an olefinic proton at $\delta 7.09$ with a carbonyl carbon at $\delta 170.1$ suggested the presence of an amide carbonyl group at one end of the polyketide chain. The presence of a guanidine group at the other end of the chain was confirmed based on the $\mathrm{HMBC}$ correlations observed between the $-\mathrm{NCH}_{3}$ group $\left(\delta_{\mathrm{H}} 3.00 ; \delta_{\mathrm{C}} 35.8\right)$ with a quaternary carbon at $\delta$ 157.7 and a methylene group at $\delta 50.0(\mathrm{C}-28)$. This was further supported by comparison of the proton and carbon chemical shifts of this methyl group and the quaternary carbon of guanidine group with those of reported data for arginomycin [10].

The anomeric proton at $\delta 4.20\left(\delta_{\mathrm{C}} 102.9\right)$ confirmed the presence of a sugar moiety in 1 . The COSY correlations observed between oxy-methine protons at $\delta 3.27\left(\delta_{\mathrm{C}} 74.6\right)$, $3.36\left(\delta_{\mathrm{C}} 77.6\right), 3.41\left(\delta_{\mathrm{C}} 72.9\right), 3.40\left(\delta_{\mathrm{C}} 76.2\right)$ and the anomeric proton (Fig. 4) indicated that the sugar was a hexuronic acid. This was further confirmed by the presence of a HMBC cross peak between oxy-methine proton at $\delta 3.41$ to carbonyl carbon at $\delta$ 176.1. The HMBC correlations between anomeric proton and carbon with the C-13 carbon and proton $\left(\delta_{\mathrm{C}} 93.8\right.$ and $\left.\delta_{\mathrm{H}} 3.58\right)$ indicated that this was the point of attachment of the sugar moiety.

The sharp singlet peak of two methylene groups at $\delta 2.35\left(\delta_{\mathrm{C}} 31.0\right)$ having long range correlation with carbons at $\delta 111.4,199.3$ and 31.0 indicated the presence of aminohydroxycyclopentenone group attached to the carbonyl carbon of the polyketide chain by an amide bond; a similar group to that of an antifungal agent ECO-02301 [3]. Accordingly the structure of ECO-0501 was confirmed, as that predicted by genomic analysis. The compound was further modified into corresponding mono- and di-methyl 


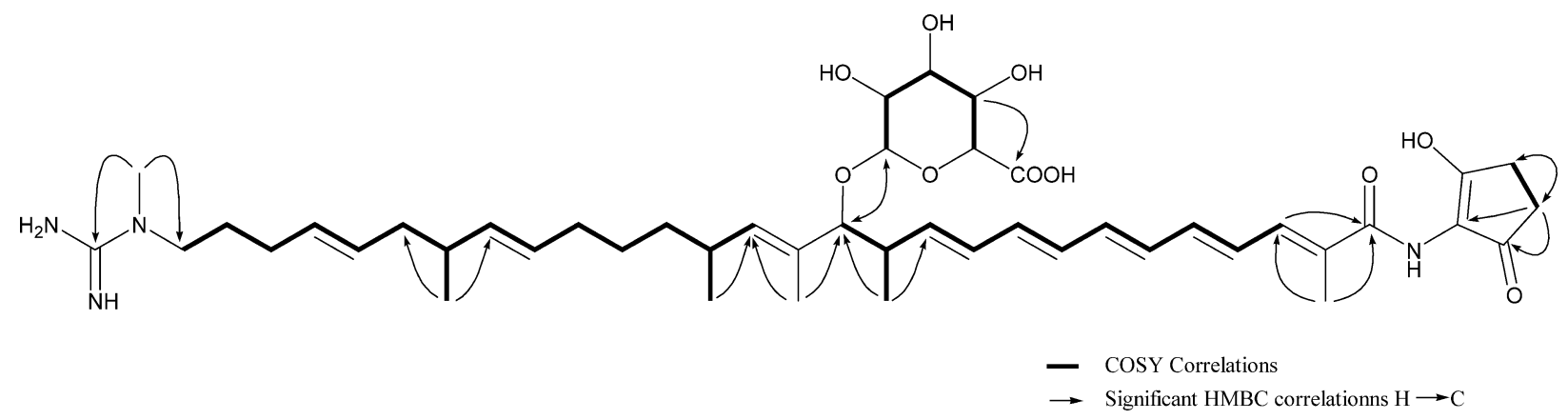

Fig. 4 ECO-0501 (1): COSY and significant HMBC correlations.

Table 3 Antibacterial activity of compound 1; minimal inhibition concentrations (MICs) are expressed in $\mu \mathrm{g} / \mathrm{ml}$

\begin{tabular}{|c|c|c|}
\hline Strain & Compound 1 & Vancomycin \\
\hline Staphylococcus aureus ATCC ${ }^{\mathrm{TM}} 6538 \mathrm{P}$ & 2 & 2 \\
\hline S. aureus ATCC 700699 & 4 & 4 \\
\hline S. epidermidis ATCC ${ }^{\text {TM }} 12228$ & 4 & 2 \\
\hline Bacillus subtilis ATCC ${ }^{\mathrm{TM}} 23857$ & 1 & 0.25 \\
\hline B. megaterium ATCC ${ }^{\mathrm{TM}} 14581$ & 1 & 0.125 \\
\hline Enterococcus faecalis ATCC ${ }^{\text {TM }} 29212$ & $8 \sim 16$ & 4 \\
\hline E. faecalis ATCC ${ }^{\mathrm{TM}} 51299$ & 16 & $8 \sim 16$ \\
\hline Micrococcus luteus ATCC ${ }^{\mathrm{TM}} 9341$ & 4 & 1 \\
\hline
\end{tabular}

esters $(\mathbf{1 a} \sim \mathbf{1 c})$ by treating with dimethyl sulphate in $\mathrm{MeOH}$. An $N$-acetyl derivative (1d) was obtained via acetylation of ECO-0501 with acetic anhydride, while a decatetrahydro derivative (1e) was produced by hydrogenolysis of $\mathbf{1}$ in the presence of $\mathrm{PtO}_{2}$ in $\mathrm{MeOH}$.

The compounds were tested for their antibacterial activity against pathogenic strains. The minimal inhibitory concentrations (MICs) are summarized in Table 4. ECO0501 (1) possessed significant antibacterial activity against all strains tested. The MIC values were comparable to that of vancomycin, which was used as a control. In low $\mathrm{pH}$ (5.0 and 6.0), compound $\mathbf{1}$ showed stronger antibacterial activity than vancomycin against $S$. aureus (ATTC 6538P). All the modified products i.e., methyl esters $(\mathbf{1} \mathbf{a} \sim \mathbf{1 c}), N$-acetyl derivative (1d) and decatetrahydro derivative (1e) were less potent against $S$. aureus (ATTC 6538P) as shown in Table 4 , indicating the importance, for antibacterial activity, of the free acids as well as the polyene chromophore. The decahydroderivative (1e) was inactive to $32 \mu \mathrm{g} / \mathrm{ml}$ in this assay.

Preliminary work aimed at defining the mode of action of ECO-0501 suggested that this compound exerts its bactericidal properties through a potentially novel cell
Table 4 Compounds $\mathbf{1}$ to $\mathbf{1 d}$ antibacterial activity on $S$. aureus (ATCC ${ }^{\text {TM }}$ 6538P), and effect of $\mathrm{pH}$; minimal inhibition concentrations (MICs) are expressed in $\mu \mathrm{g} / \mathrm{ml}$

\begin{tabular}{lllllll}
\hline & $\mathbf{1}$ & $\mathbf{1 a}$ & $\mathbf{1 b}$ & $\mathbf{1 c}$ & $\mathbf{1 d}$ & Vancomycin \\
\hline $\mathrm{pH} 5.0$ & 0.125 & 2 & 2 & 2 & 0.25 & 1 \\
$\mathrm{pH} 6.0$ & 0.25 & $4 \sim 8$ & 2 & 4 & 0.5 & 1 \\
$\mathrm{pH} 7.0$ & 1 & 16 & 2 & 4 & 2 & 1 \\
\hline
\end{tabular}

membrane and/or cell wall target specific to bacteria. Furthermore, ECO-0501 displayed efficacy in a mouse model of $S$. aureus infection when given i.p. (data not shown).

\section{Experimental}

\section{General}

The NMR spectra were measured on a Varian Unity Inova $500 \mathrm{MHz}$ spectrophotometer with methanol- $d_{4}$. Solutions, and are referenced to TMS. The analytical HPLC was carried out with a Waters Alliance 2690 instrument equipped with a Micromass ZQ electrospray source and Waters 996 diode array UV detectors. Semi-preparative HPLCs were done either on a Waters 1525 instrument with Waters 2996 diode array UV detector or on Waters Autopurification System with At Column Dilution (ACD). All the chemicals and solvents used for the purifications were HPLC grade.

\section{Genome Scanning}

The genome of $A$. orientalis ATCC 43491 was analyzed by genome scanning technique as described previously by Zazopoulos et al. [2]. The DNA and protein sequences that comprise the ECO-0501 gene cluster are deposited in GeneBank under accession numbers Contig1 DQ884174, 
Contig2 DQ884175, Contig3 DQ884176.

\section{Fermentation}

A. orientalis ATCC 43491, which was obtained from the American Type Culture Collection (P.O. Box 1549, Manassas, VA 20108, USA), was cultivated on agar plates of ISP2 medium (Difco). To prepare a vegetative culture, $A$. orientalis ATCC 43491 was grown on ISP2 agar (Difco) for 5 to 7 days, and the surface growth from the agar plate was homogenized and transferred to a $125 \mathrm{ml}$ flask containing three glass beads ( $5 \mathrm{~mm}$ diameter), and $25 \mathrm{ml}$ of sterile medium prepared from trypticase soy broth (Bacto) $30 \mathrm{~g}$, yeast extract $3 \mathrm{~g}, \mathrm{MgSO}_{4} 2 \mathrm{~g}$, glucose $5 \mathrm{~g}$, maltose $4 \mathrm{~g}$, to which one liter distilled water was added. This vegetative culture was incubated at $28^{\circ} \mathrm{C}$ for about 60 hours on a shaker with a $2.5 \mathrm{~cm}$ throw and set at $250 \mathrm{rpm}$.

The vegetative culture $(10 \mathrm{ml}$ aliquots $)$ was used to inoculate 2 liter baffled flasks each containing $500 \mathrm{ml}$ of sterile production medium prepared from glucose $10 \mathrm{~g}$, glycerol $5 \mathrm{~g}$, corn steep liquor $3 \mathrm{~g}$, beef extract $3 \mathrm{~g}$, malt extract $3 \mathrm{~g}$, yeast extract $3 \mathrm{~g}$, calcium carbonate $2 \mathrm{~g}$, thiamine $0.1 \mathrm{~g}$ made up to one liter with distilled water [11]. The medium was adjusted at $\mathrm{pH} 7.0$, and then $1 \mathrm{ml}$ of silicon defoamer-oil (Chem Service) was added to each flask before sterilization. The fermentation batches were incubated aerobically on a shaker $(200 \mathrm{rpm})$ at $28^{\circ} \mathrm{C}$ for a period of 4 days.

\section{Isolation of ECO-0501 (1)}

The mycelia and broth of the culture media $(12 \times 500 \mathrm{ml})$ was separated by centrifugation $(3000 \mathrm{rpm}, 20 \mathrm{~min})$. The mycelial cake was extracted consecutively with methanol ( $200 \mathrm{ml} /$ liter broth) and acetone $(200 \mathrm{ml} /$ liter $)$ to produce an organic cell extract. The organic extract was used for further purification by two different methods.

\section{Method A}

The combined organic extract was dried under vacuum, and further suspended in a mixture of $\mathrm{MeOH} /$ aqueous $\mathrm{NH}_{4} \mathrm{HCO}_{3}$ solution adjusted to $\mathrm{pH} 10$ with $\mathrm{NH}_{4} \mathrm{OH}(3: 2$, $100 \mathrm{ml} /$ liter original broth volume) and consecutively extracted by $\mathrm{CHCl}_{3}(100 \mathrm{ml} /$ liter $)$ and $n-\mathrm{BuOH}(100 \mathrm{ml} /$ liter $)$. The $\mathrm{BuOH}$ fraction was concentrated, and the residue was dissolved in a minimal amount of $\mathrm{DMSO} / \mathrm{MeOH}(3: 1)$ and subjected for HPLC purification after filtering through a $0.45 \mu \mathrm{m} 13 \mathrm{~mm}$ Acrodisc GHP syringe filter. The HPLC was performed on a Waters Autopurification System with ACD using a Waters Xterra MS C18 column (5 $\mu$, $19 \times 150 \mathrm{~mm}$ ), and a gradient of $10 \mathrm{mM}$ aqueous $\mathrm{NH}_{4} \mathrm{HCO}_{3}$ (pH 10)/acetonitrile $85: 15$ to $25: 75$ over 30 minutes at $19 \mathrm{ml} /$ minute, UV detector set at $261 \mathrm{~nm}$. The semi-purified
ECO-0501 $(1,1.04 \mathrm{~g})$, eluting at $11.8 \sim 12.1$ minutes, was collected.

ECO-0501 (1, $37.4 \mathrm{mg} /$ liter) was purified by repeated HPLC on a Waters Autopurification System with ACD using a Waters RCM Column (Novapak C-18, $6 \mu$, $40 \times 200 \mathrm{~mm}$ ) with a gradient of $10 \mathrm{mM}$ aqueous $\mathrm{NH}_{4} \mathrm{OAc}$ adjusted to $\mathrm{pH} 5$ with glacial $\mathrm{AcOH} /$ acetonitrile from $80: 20 \mathrm{v} / \mathrm{v}$ to $20: 80$ over 25 minutes at $35 \mathrm{ml} /$ minute.

\section{Method B}

The combined organic extract, which was dried under vacuum was suspended in a mixture of $\mathrm{MeOH}$ and aqueous $\mathrm{NH}_{4} \mathrm{HCO}_{3}$ solution adjusted to $\mathrm{pH} 10$ with $\mathrm{NH}_{4} \mathrm{OH}(3: 2$, $100 \mathrm{ml} /$ liter $)$ and extracted with hexane $(3 \times 100 \mathrm{ml} /$ liter original broth volume) to remove fatty substances. The aqueous methanolic fraction was then adsorbed (slurrymode) on Diaion HP-20 resin $(30 \mathrm{ml} /$ liter of fermentation broth) and applied to SPE on a Startat C-18 Cartridge (Phenomenex) with a precolumn of Diaion HP-20 resin $(70 \mathrm{ml})$. The column was subsequently eluted with a step gradient of $\mathrm{EtOH} /$ aqueous $\mathrm{NH}_{4} \mathrm{HCO}_{3}$ buffer $\mathrm{pH} 10$ to collect one $500 \mathrm{ml}$ fraction and then seven fractions $(200 \mathrm{ml}$ each) i.e., $1: 9$ (fraction 1 ); $1: 4$ (fraction 2 ); $3: 7$ (fraction 3); $2: 3$ (fraction 4 ); $1: 1$ (fraction 5 ); $3: 2$ (fraction 6 ); $8: 1$ (fraction 7) and EtOH (fraction 8). Fractions $4 \sim 7$ were pooled, concentrated and the residue was subjected for HPLC (Waters Autopurification System with ACD), using a Symmetry C18 column $(5 \mu, 30 \times 100 \mathrm{~mm})$ with a gradient of $10 \mathrm{mM}$ aqueous $\mathrm{NH}_{4} \mathrm{OAc}$, (adjusted to $\mathrm{pH} 5$ with glacial $\mathrm{AcOH}$ )/acetonitrile $74: 26 \mathrm{v} / \mathrm{v}$ to $50: 50$ over 20 minutes at $39 \mathrm{ml} / \mathrm{minute}$. The collection was triggered by UV absorption at $261 \mathrm{~nm}$ (PDA). The sample was loaded as a suspension in DMSO : $\mathrm{MeOH}(3: 1)$. ECO0501, which eluted at $14.9 \sim 15.2$ minutes, was pure.

1: UV $\left(\lambda_{\max }\right) 258$ and $362 \mathrm{~nm}$; MS (ESI in positive mode) $\mathrm{m} / z 837.5(\mathrm{M}+\mathrm{H})^{+}, 823.5\left(\mathrm{M}+\mathrm{H}-\mathrm{CH}_{3}\right)^{+}$; MS (ESI in negative mode) $\mathrm{m} / \mathrm{z} 835.3(\mathrm{M}-\mathrm{H})^{-}, 821.5$ $\left(\mathrm{M}-\mathrm{H}-\mathrm{CH}_{3}\right)^{-}$; HRMS 837.5018 calcd for $\mathrm{C}_{46} \mathrm{H}_{69} \mathrm{~N}_{4} \mathrm{O}_{10}$ $(\mathrm{M}+\mathrm{H})^{+}$837.5014. The ${ }^{1} \mathrm{H}$ and ${ }^{13} \mathrm{C}$ NMR data are in Table 1 .

\section{Synthesis of 1a $\sim 1 \mathbf{c}$}

A solution of $1(20 \mathrm{mg})$ in $\mathrm{MeOH}(2.0 \mathrm{ml})$ was stirred with a mixture of $0.1 \mathrm{mM} \mathrm{NaOH}$ (Fisher Chemicals) solution in $\mathrm{MeOH}(334 \mu 1)$ and dimethyl sulfate $(5.68 \mu 1$, Sigma) at room temperature for 24 hours. The reagents were successively added to the reaction mixture after 24 and 48 hours $(\mathrm{NaOH}$ solution 300 and $400 \mu \mathrm{l}$; dimethyl sulphate 10 and $15 \mu \mathrm{l}$ ). The reaction was monitored by TLC (Merck Silica gel $60 \mathrm{~F}_{254}$, eluted with $7 \%$ methanol in chloroform, visualized under UV) and stopped after 72 hours. The 
reaction mixture was purified by HPLC on a Waters AutoPurification System using a Symmetry column (C-18, $5 \mu$, $30 \times 100 \mathrm{~mm}$ ) with $10 \mathrm{mM} \mathrm{NH} \mathrm{NH}_{4} \mathrm{OAc}$ in water $/ \mathrm{MeCN}$ gradient ( $74: 26 \mathrm{v} / \mathrm{v}$ to $50: 50$ in 20 minutes, $40 \mathrm{ml} /$ minute). The monomethyl derivatives $\mathbf{1 b}(0.53 \mathrm{mg}), \mathbf{1 a}(5.36 \mathrm{mg})$ and a dimethyl derivative 1 c $(4.04 \mathrm{mg})$ were eluted at 9.4 , 11.5 and 15.5 minutes, respectively.

1a: UV $\left(\lambda_{\max }\right) 258$ and $362 \mathrm{~nm}$; MS (ESI in positive mode) $\mathrm{m} / z 852.03(\mathrm{M}+\mathrm{H})^{+}$; MS (ESI in negative mode) $m / z 849.97\left(\mathrm{M}-\mathrm{H}^{-}\right)$. The ${ }^{1} \mathrm{H}$ and ${ }^{13} \mathrm{C}$ NMR data are in Table 2.

1b: UV $\left(\lambda_{\max }\right) 258$ and $362 \mathrm{~nm}$; MS (ESI in positive mode) $\mathrm{m} / z 852.03(\mathrm{M}+\mathrm{H})^{+}$; MS (ESI in negative mode) $m / z 849.98(\mathrm{M}-\mathrm{H})^{-}$. The ${ }^{1} \mathrm{H}$ and ${ }^{13} \mathrm{C}$ NMR data are in Table 2.

1c: UV $\left(\lambda_{\max }\right) 258$ and $362 \mathrm{~nm}$; MS (ESI in positive mode) $\mathrm{m} / z 866.06(\mathrm{M}+\mathrm{H})^{+}$; MS (ESI in negative mode) $m / z 863.89(\mathrm{M}-\mathrm{H})^{-}$; The ${ }^{1} \mathrm{H}$ and ${ }^{13} \mathrm{C}$ NMR data are in Table 2.

Synthesis of 1d

A solution of $1(20 \mathrm{mg})$ in $\mathrm{MeOH}(2 \mathrm{ml})$ was stirred with acetic anhydride $(20 \mu \mathrm{l})$ at room temperature for 24 hours. Additional acetic anhydride $(20 \mu \mathrm{l})$ was added to the reaction mixture at 24 and 48 hours. The reaction was monitored by TLC (Merck Silica gel $60 \mathrm{~F}_{254}$, eluted with $7 \% \mathrm{MeOH}$ in chloroform, visualized under UV) and stopped at 72 hours.

The reaction mixture was purified by HPLC on a Waters Auto-Purification System using a Symmetry (C-18, $5 \mu$, $30 \times 100 \mathrm{~mm}$ ) column with $10 \mathrm{mM} \mathrm{NH} \mathrm{NH}_{4} \mathrm{OAc}$ in water adjusted to $\mathrm{pH} 5$ with glacial $\mathrm{AcOH} /$ acetonitrile gradient system ( $74: 26 \mathrm{v} / \mathrm{v}$ to $50: 50$ in 20 minutes, $40 \mathrm{ml} /$ minute). Compound $1 \mathbf{d}(6.43 \mathrm{mg})$ was obtained as a single product.

1d: UV $\left(\lambda_{\max }\right) 258$ and $362 \mathrm{~nm}$; MS (ESI in positive mode) $\mathrm{m} / z 880.03(\mathrm{M}+\mathrm{H})^{+}$; MS (ESI in negative mode) $m / z 877.98(\mathrm{M}-\mathrm{H})^{-}$; The ${ }^{1} \mathrm{H}$ and ${ }^{13} \mathrm{C}$ NMR data are in Table 2.

Synthesis of 1e

A solution of $1(20 \mathrm{mg})$ in $\mathrm{MeOH}(2 \mathrm{ml})$ was stirred under hydrogen gas overnight at room temperature in the presence of $\mathrm{PtO}_{2}(10 \mathrm{mg})$ as a catalyst. The reaction mixture was filtered and the filtrate was concentrated to obtain the decatetrahydro derivative $(\mathbf{1 e}, 18.7 \mathrm{mg})$.

1e: UV $\left(\lambda_{\max }\right) 258 \mathrm{~nm}$; MS (ESI in positive mode) $\mathrm{m} / \mathrm{z}$ $853.03(\mathrm{M}+\mathrm{H})^{+}$; MS (ESI in negative mode) $\mathrm{m} / \mathrm{z} 851.08$ $(\mathrm{M}-\mathrm{H})^{-}$. The ${ }^{1} \mathrm{H}$ and ${ }^{13} \mathrm{C}$ NMR data are in Table 2.

\section{Antibacterial Activity}

Antibacterial activity of the isolated compounds were measured by determining the minimal inhibitory concentrations (MIC) against eight pathogenic strains, namely Staphylococcus aureus (ATCC 6538P), Staphylococcus aureus MRS3 ( ${ }^{\mathrm{TM}}$ 700699), Staphylococcus epidermidis (ATCC 12228), Bacillus subtilis (ATCC 23857), Bacillus megaterium (ATCC 14581), Enterococcus faecalis VRE-1 (ATCC 29212), Enterococcus faecalis VRE-2 (ATCC 51299) and Micrococcus luteus (ATCC 9341). The antibacterial experiments were performed according to the National Committee for Clinical Laboratory Standards (NCCLS) guideline M7-A5 [12].

The stock solutions of the tested compounds were prepared in DMSO $(100 \times)$ and diluted with MuellerHinton test medium as two-fold series over 11 points from $3.2 \mathrm{mg} / \mathrm{ml}$ to $0.003 \mathrm{mg} / \mathrm{ml}$. An aliquot of each stock solution was diluted 50 -fold in test medium described below to give a set of eleven $2 \times$ solutions. Fifty microliters of each of the eleven $2 \times$ solutions were aliquoted into the corresponding wells of a 12-well row, with the final well reserved for a medium-alone control. Vancomycin (Sigma) used as positive control, which was prepared as $2 \times$ stock solutions in Mueller-Hinton test medium ranging from $64 \mu \mathrm{g} / \mathrm{ml}$ to $0.06 \mu \mathrm{g} / \mathrm{ml}$ (a two-fold dilution series over 11 points). An aliquot of $50 \mu \mathrm{l}$ of each concentration (at $2 \times$ ) was then transferred to 96 -well microplates to obtain a series of eleven two-fold dilutions.

An isolated colony of each of the eight indicator strains was used to inoculate tubes containing $2 \mathrm{ml}$ of test medium. Mueller-Hinton test medium was used for S. aureus (ATCC 6538P), S. aureus MRS3 (ATCC 700699), S. epidermidis (ATCC 12228), B. subtilis (ATCC 23857), B. megaterium (ATCC 14581) and M. luteus (ATCC 9341) indicator strains, and Brain Heart Infusion test medium was used for E. faecalis VRE-1 (ATCC 29212) and E. faecalis VRE-2 (ATCC 51299) indicator strains. Cells were grown overnight at $35^{\circ} \mathrm{C}$ with shaking. Inoculum density for each indicator strain was adjusted to $\mathrm{OD}_{600}=0.1$ in $5 \mathrm{ml} 0.85 \%$ saline, then further diluted $1 / 100$ in appropriate medium. $50 \mu \mathrm{l}$ of the final dilution (in test medium) of each indicator strain was added to each well of a 12-well row. This brings the final dilution of the test compound or control compound in solution to $1 \times$. The final inoculum has approximately $5 \times 10^{5} \mathrm{CFU} / \mathrm{ml}$.

The indicator strains were incubated with 11 concentrations of each of test compounds, vancomycin (Sigma) control and one medium-alone control. For MIC determination, assay plates were incubated at $35^{\circ} \mathrm{C}$ for 16 to 20 hours. The MIC for each indicator was assessed as the lowest concentration of the compound resulting in total absence of growth and is shown in Table 3. 


\section{References}

1. Zazopoulos E, Huang K, Staffa A, Liu W, Bachmann BO, Nonaka K, Ahlert J, Thorson JS, Shen B, Farnet CM. A genomics-guided approach for discovering and expressing cryptic metabolic pathways. Nat Biotechnol 21: 187-190 (2003).

2. Zazopoulos E, Farnet CM. Improving drug discovery from Microorganisms. Natural Products: Drug Discovery and Therapeutic Medicine; Zhang, Demain eds., pp. 95-106 (2005)

3. McAlpine JB, Bachmann BO, Piraee M, Tremblay S, Alarco AM, Zazopoulos E, Farnet CM. Microbial genomics as a guide to drug discovery and structural elucidation: ECO02301, a novel antifungal agent, as an example. J Nat Prod 68: 493-496 (2005)

4. Banskota AH, McAlpine JB, Sørensen D, Aouidate M, Piraee M, Alarco AM, Ōmura S, Shiomi K, Farnet CM, Zazopoulos E. Isolation and identification of three new 5Alkenyl-3,3(2H)-furanones from two Streptomyces species using a genomic screening approach. J Antibiot 59: 168-176 (2006)

5. Sørensen D, McAlpine JB, Piraee M, Farnet CM, Zazopoulos E. Genome scanning technology reveals an antibacterial compound (ECO-0501) of a new structural class from the vancomycin-producer Amycolatopsis orientalis. 44th ICAAC: No. F-720a, Washington, DC (2004)

6. McAlpine JB, Zazopoulos E, Sørensen D, Piraee M, Ibrahim A, Aouidate M, Farnet CM. The power of genomic analysis in the discovery of novel secondary metabolites. 46th Annual Meeting of American Society of Pharmacognosy: No. O-21, Corvallis (2005)

7. Nakagawa A, Wu TS, Keller PJ, Lee JP, Ōmura S, Floss HG. Biosynthesis of asukamycin. Formation of the 2- aminocyclopentenol-3-one moiety. J Chem Soc Chem Commun 519-521 (1985)

8. Caffrey P. Conserved amino acid residues correlating with ketoreductase stereospecificity in modular polyketide synthases. Chembiochem 4: 654-657 (2003)

9. Block K, Pedersen C. Carbon 13 nuclear magnetic resonance spectroscopy of monosaccharides. In Advances in Carbohydrate Chemistry and Biochemistry, Vol. 41, pp. 27-66 (1983) Academic Press

10. Argoudelis AD, Baczynskyj L, Kuo MT, Laborde AL, Sebek OK, Truesdell SE, Shilliday FB. Arginomycin: production, isolation, characterization and structure. J Antibiot 11: 750-760 (1987)

11. Kanzaki H, Wada K, Nitoda T, Kawazu K. Novel bioactive oxazolomycin isomers by Streptomyces albus JA3453. Biosci Biotechnol Biochem 62: 438-442 (1998)

12. Methods for Dilution Antimicrobial Susceptibility Tests for Bacteria That Grow Aerobically; Approved Standard-Fifth Edition. (NCCLS document M7-A5, ISBN 1-56238-394-9; NCCLS, 940 West Valley Road, Suite 1400, Wayne, Pennsylvania 19087-1898 USA)

13. Yamakawa T, Furumai T, Yoshida R, Igarashi Y. Clethramycin, a new inhibitor of pollen tube growth with antifungal activity from Streptomyces hygroscopicus TP-A0623 I. Screening, taxonomy, fermentation, isolation and biological properties. J Antibiot 56: 700-704 (2003)

14. Igarashi Y, Iwashita T, Fujita T, Naoki H, Yamakawa T, Yoshida R, Furumai T. Clethramycin, a new inhibitor of pollen tube growth with antifungal activity from Streptomyces hygroscopicus TP-A0623. II Physico-chemical properties and structure determination. J Antibiot 56: 705-708 (2003)

15. Clethramycin was isolated and identified independently at Ecopia Biosciences and correlated with its biosynthetic locus (data not shown) 